\title{
Perihilar Bile Duct Cancer Pathologic Regional Lymph Nodes TNM Finding v8
}

National Cancer Institute

\section{Source}

National Cancer Institute. Perihilar Bile Duct Cancer Pathologic Regional Lymph Nodes

TNM Finding v8. NCI Thesaurus. Code C134731.

A pathologic finding about one or more characteristics of perihilar bile duct cancer,

following the rules of the TNM AJCC v8 classification system as they pertain to staging of regional lymph nodes. 